\title{
On the relationship between ENSO and tropical cyclones in the western North Pacific during the boreal summer
}

\author{
Haikun Zhao ${ }^{1}$. Chunzai Wang ${ }^{2}$ \\ Received: 20 October 2017 / Accepted: 10 February 2018 / Published online: 19 February 2018 \\ (c) The Author(s) 2018. This article is an open access publication
}

\begin{abstract}
The present paper uses the satellite era data from 1979 to 2015 to examine the relationship between El Niño-Southern Oscillation (ENSO) and tropical cyclones (TCs) in the western North Pacific (WNP) during the boreal summer from June to August. It is found that WNP TC variability is characterized by two major feature changes: (1) a significant reduction of the TC number since 1998 and (2) a stronger interannual relationship between ENSO and TCs since 1998. Results suggested that such changes are largely due to the synergy effects of a shifting ENSO and the Pacific climate regime shift. Since 1998 with a cool Pacific decadal oscillation phase switching from a warm phase, more La Niña and central Pacific (CP) El Niño events occur. The decreased low-level relative vorticity and increased vertical wind shear during 1998-2015 compared to 1979-1997 are responsible for the TC reduction. The stronger interannual relationship between ENSO and TCs since 1998 is closely associated the change of CP sea surface temperature. It enhances the associations of environmental factors including vertical wind shear and mid-level relative humidity with TCs and thus increases the interannual relationship between ENSO and TCs. These two feature changes also manifest in the mean TC genesis location, with a northwestward shift of the TC genesis location during 1998-2015 and an increased relation to El Niño Modoki index since 1998. This study has an important implication for TC outlooks in the WNP based on climate predictions and projections.
\end{abstract}

Keywords Tropical cyclone variability and climate $\cdot$ ENSO $\cdot$ Pacific decadal oscillation $\cdot$ Interdecadal change of interannual relationship

\section{Introduction}

Tropical cyclone (TC) is one of the most devastating weather phenomena on earth. Studies suggested that TCinduced damages tend to show an increased trend over the past several decades (Pielke et al. 2008; Zhang et al. 2009; Mendelsohn et al. 2012; Peduzzi et al. 2012). It has been

Chunzai Wang

cwang@scsio.ac.cn

1 Key Laboratory of Meteorological Disaster of the Ministry of Education, Joint International Research Laboratory of Climate and Environment Change, Collaborative Innovation Center on Forecast and Evaluation of Meteorological Disasters, Pacific Typhoon Research Center, Earth System Modelling Center, Nanjing University of Information Science and Technology, Nanjing 210044, China

2 State Key Laboratory of Tropical Oceanography, South China Sea Institute of Oceanology, Chinese Academy of Sciences, Guangzhou, China in turn raised increasing concerns on connection between climate change and TCs. The western North Pacific (WNP) is one of the most active ocean basins and experiences about 27 TCs each year, accounting for almost one-third of the world's annual TC counts (Chan 2005). These TCs often lead to substantial loss of life and property damage to China and adjacent countries (Zhang et al. 2009, 2013). A better understanding of the variability of WNP TC activity and the associated physical mechanisms therefore has a profound socio-economic impact as well as scientific significance.

On interannual time scale, El Niño-Southern Oscillation (ENSO) has been well known to be a major factor in modulating interannual variability of WNP TC activity (Lander 1994; Chan 2000; Wang and Chan 2002; Camargo and Sobel 2005; Zhao et al. 2010, 2011). A general consensus can be reached that ENSO has no noticeable impact on the total TC frequency but has a pronounced impact on the displacement of the mean TC formation location. During El Niño years, more TCs occur over the southeastern quadrant of the WNP and tend to move northwestward, causing more TCs with a 
longer duration and a stronger intensity because of a longer distance over the tropical warm waters (Camargo and Sobel 2005; Chan 2008; Zhan et al. 2011). In this paper, we show a significantly increased relationship between the Niño-3.4 index and the WNP TC frequency in the boreal summer (June to August; JJA) during the recent decades. We also address what cause the increased association between the JJA WNP TC frequency and ENSO in the recent decades?

On longer or decadal time scale, the Pacific decadal oscillation (PDO) can cause the WNP TC variability (Chan 2008; Maue 2011; Liu and Chan 2013; Wang et al. 2010, 2015; Wang and Liu 2015; Zhao and Wang 2016). Liu and Chan (2013) and Maue (2011) respectively described significant reductions of the WNP TC frequency and of global TC activity over the TC season since the late 1990s. They qualitatively explained the decrease in the frequency of TCs as interdecadal changes in atmospheric and oceanic conditions affecting TC genesis associated with the shift of the Pacific mean-state climate in 1998. Recently, Zhao and Wang (2016) showed a similar abrupt reduction of WNP TC activity around 1998 in the late season from October to December and pointed that it was associated with the interdecadal change of the relationship between the PDO and ENSO. However, the influence of interdecadal PDO associated with current climate regime shift around the late-1990s on the interannual ENSO-TC relationship during the boreal summer is less studied.

Moreover, there is evidence to link the prevalence of one type of El Niño event or the other to decadal variations of the mean state of the Pacific associated with the PDO (Verdon and Franks 2006). The cold phase of the PDO since the late1990s is likely to favor La Niña or CP El Niño events. Recent studies also demonstrated that a regime shift in ENSO in the recent decades with more frequent La Niña and CP El Niño events (Kao and Yu 2009; Xiang et al. 2013; Cai et al. 2015). Associated with changes in sea surface temperature (SST) related to a shifting ENSO and Pacific climate regime shift, large-scale atmospheric and oceanic environmental variables affecting TC activity show corresponding changes (Kim et al. 2009, 2011; Han et al. 2016; Wang and Wu 2016; Huangfu et al. 2017, Hsu et al. 2014; Choi et al. 2015; Hong et al. 2016; He et al. 2017). Additionally, previous many studies suggested some inter-annual remote teleconnections to the WNP TC frequency (e.g., North Atlantic Oscillation, Zhou and Cui 2014; Arctic Oscillation; Cao et al. 2016; the SST gradient between the Southwest Pacific and the Western Pacific Warm Pool; Zhao et al. 2016) have experienced a significant interdecadal change. However, the interannual correlation between ENSO and WNP TC activity was not discussed by these previous studies. In terms of the interdecadal changes of WNP TC activity and its association with some tele-connections mentioned above, a question naturally arises: Have the shifting ENSO and Pacific climate regime switch changed the interannual relationship between ENSO and the boreal summer TC frequency in the WNP?

The remainder of the paper is organized as follows. Section 2 describes the data and methodology used in this paper. Section 3 documents the increased interannual relationship between ENSO and the TC frequency, and longer-term shift of the WNP TC activity. The plausible physical causes for the increased interannual relationship and longer-term TC activity shift are explored in Sect. 4 . The summary and discussion are given in Sect. 5.

\section{Datasets}

\subsection{TC data}

The TC dataset used in this study is obtained from the United States Joint Typhoon Warning Center (JTWC) best track dataset. It includes information on the TC locations (latitude and longitude) and intensity at a 6-hour interval. Our study focuses on the boreal summer from June to August (JJA). Since TC observations are more reliable after the satellite era, we use the TC data from 1979 to 2015 . The TC frequency in this study is counted over the WNP main development region (MDR) $\left(5-25^{\circ} \mathrm{N}, 100-180^{\circ} \mathrm{E}\right)$. The $\mathrm{TC}$ genesis location is defined as the first position at which the TC intensity exceeds or equals to 35 knots. To confirm the results of this study, we also perform the same analyses from the other two widely used best track datasets: the China Meteorological Administration-Shanghai Typhoon Institute (CMA_STI) and Japan Meteorological Agency (JMA). The relationship between ENSO and the JJA TC frequency used these two TC datasets are almost identical to that used the JTWC data, which will be shown in Sect. 3 .

\subsection{Atmospheric data and SST data}

The atmospheric fields (e.g., relative humidity and winds) are from the United States National Centers for Environmental Prediction and National Center for Atmospheric Research (NCEP/NCAR) monthly Reanalysis II dataset in a $2.5^{\circ} \times 2.5^{\circ}$ grid (Kanamitsu et al. 2002). The monthly mean SST is from the United States National Oceanic and Atmospheric Administration (NOAA) Extended Reconstruction SST version 4 (ERSSTv4) at a horizontal resolution of $2^{\circ} \times 2^{\circ}$ (Huang et al. 2015, 2016).

\subsection{ENSO indices and significance test}

To better understand the relationship between the TC frequency and different ENSO flavors, various ENSO indices including the Niño-3, Niño-3.4 and El Niño Modoki index (EMI) are used in this study. Although the Niño-3.4 index 
is generally used to describe the ENSO state change, it is a mixture of Niño-3 and Niño-4 and does not well separate the central-Pacific (CP) and eastern-Pacific (EP) ENSO events. As suggested in previous studies (Yu et al. 2012; Xiang et al. 2013; Cai et al. 2015; Zhao et al. 2016), two types of ENSO events show a distinct teleconnected impact on climate and extreme weather events around the globe. We use the Niño-3 index to represent EP ENSO events and the EMI to represent CP ENSO events. The EMI is calculated by following Ashok et al. (2007):

$\mathrm{EMI}=[\mathrm{SSTA}]_{\mathrm{C}}-0.5 \times[\mathrm{SSTA}]_{\mathrm{W}}-0.5 \times[\mathrm{SSTA}]_{\mathrm{E}}$,

where the brackets indicate the SST anomalies averaged in Regions $\mathrm{C}\left(165^{\circ} \mathrm{E}-140^{\circ} \mathrm{W}, 10^{\circ} \mathrm{S}-10^{\circ} \mathrm{N}\right), \mathrm{W}\left(125^{\circ} \mathrm{E}-145^{\circ} \mathrm{E}\right.$, $\left.10^{\circ} \mathrm{S}-20^{\circ} \mathrm{N}\right)$, and $\mathrm{E}\left(110^{\circ} \mathrm{W}-70^{\circ} \mathrm{W}, 15^{\circ} \mathrm{S}-5^{\circ} \mathrm{N}\right)$, respectively. The EMI was adopted in many previous studies for representing CP ENSO events (Ashok et al. 2007; Kim et al. 2009; Chen and Tam 2010; Hong et al. 2011; Zhao et al. 2016).

According to the definition of ENSO diversity with a threshold of 0.6 s.d., we identify five EP El Niño events (1982, 1983, 1987, 1997, and 2015) and seven CP El Niño events (1991, 1994, 2002, 2003, 2004, 2006, and 2009) (Table 1). Due to no substantial zonal changes of La Niña SST distribution as suggested by previous studies (Kug et al. 2009; Ren and Jin 2011), we classify La Niña events into one category and thus 11 La Niña events can be identified (1985, 1988, 1995, 1996, 1998, 1999, 2000, 2007, 2010, 2011, and 2013) (Table 1). The selection of these three ENSO-type events is generally consistent well with the current common methods for ENSO diversity (i.e., the EP-index and CP-index method, Kao and Yu 2009; the NCT and NWP method; Ren and Jin 2011; the Niño-3.4 and Niño-3.4b, Hu et al. 2016).

There is evidence to link the prevalence of one type of El Niño or the other to decadal variations in the mean state of the Pacific associated with the PDO (Verdon and Franks 2006). By restricting wind anomalies and convection to the $\mathrm{CP}$ region, the current cool PDO phase is likely to favor La Niña or CP El Niño events, very much as has been observed since the late-1990s or the early-2000s (Xiang et al. 2013). As seen from Table 1, more EP El Niño events and less La

Table 1 Classification of different ENSO flavors during the cool PDO phase (1998-2015) and warm PDO phase (1979-1997)

\begin{tabular}{lll}
\hline & $\begin{array}{l}\text { PDO warm phase } \\
1979-1997\end{array}$ & PDO cold phase 1998-2015 \\
\hline EP El Niño & $1982,1983,1987,1997$ & 2015 \\
CP El Niño & 1991,1994 & $2002,2003,2004,2006$, \\
& & 2009 \\
La Niña & $1985,1988,1995,1996$ & $1998,1999,2000,2007$, \\
& & $2010,2011,2013$ \\
\hline
\end{tabular}

Niña events can be found during 1979-1997. However, only one EP El Niño event in 2015 while more frequent La Niña and CP El Niño events were observed during 1998-2015. Such interdecadal changes of ENSO flavors are in well consistence with the shifting ENSO and the Pacific climate shift as suggested by previous studies (Verdon and Franks 2006; Kao and Yu 2009; Xiang et al. 2013; Cai et al. 2015).

Student's $t$ test was usually performed for statistical significance, but it is assumed that two random variables both follow a Gaussian distribution. However, the relative small sample size in our analysis for the whole period (37-year for 1979-2015) and the two sub-periods (19-year for 1979-1997 and 18-year for 1998-2015), it is not guaranteed that the samples are characterized by the Gaussian distribution. Thus, instead of using a Student's t test, the non-parametric Mann-Kendall test (Mann 1945; Kendall 1975) and the Wilcoxon-Mann-Whitney test (Wilcoxon 1945; Mann and Whitney 1947) are respectively used to assess the statistical significance of the correlation and the difference (Chu 2002). Such the test was widely used in previous studies (Chu 2002; Chu and Zhao 2004; Hsu et al. 2014; Zhao and Wang 2016).

\section{TC variability in the WNP}

TC variability in the WNP during 1979-2015 is characterized by two major feature changes (Fig. 1). The first one is a longer-term (or interdecadal) reduction of the TC number, and the other one is an increased change of the interannual relationship between ENSO and the TC number.

\subsection{Longer-term TC variability}

Figure 1 shows the time series of the JJA TC frequency from the JTWC dataset in the WNP and Niño-3.4 index during 1979-2015. An interdecadal change of the TC frequency is clearly shown: the TC number during 1998-2015 is largely reduced in comparison with the number during 1979-1997. The averaged TC number in JJA during 1979-1997 is about 10.5 TCs per year, which is significantly (above the 95\% confidence level) larger than 8.5 TCs per year during 1998-2015. Inspiringly, the significant reduction of the JJA TC number over the WNP basin can be also found after 1998 from the CMA_STI and JMA datasets (Table 2). In fact, the abrupt reduction of the JJA TC frequency around 1998 in the WNP is clearly seen in the analysis based on the change-point approach developed by Chu and Zhao (2004) (figure not shown). The change-point approach was widely used in previous studies to detect the abrupt shift (Chu and Zhao 2004; Tu et al. 2009; Hsu et al. 2014; Zhao and Wang 2016). This reduction of the TC number coincides with the phase switch of the PDO. 
The mean TC genesis location shows a similar interdecadal change. A significant westward shift and moderate northward displacement of the TC genesis from the JTWC can be observed during 1998-2015 (Table 2). During 1979-1997, the average TC genesis longitude from the JTWC is about $135.6^{\circ} \mathrm{E}$, while $132.2^{\circ} \mathrm{E}$ is found during 1998-2015. Their difference of $3.4^{\circ}$ is significant at the $95 \%$ confidence level. The westward shift of the TC genesis location is consistent with the warm SST located in the WNP during 1998-2015 (shown in next section). However, the average TC genesis latitude shows a moderate displacement. The mean genesis latitude is $16.4^{\circ} \mathrm{N}$ during $1998-2015$ and $16.8^{\circ} \mathrm{N}$ during $1979-1997$ (Table 2). Such a northwestward displacement of mean TC genesis location can be also seen from the CMA_STI and JMA during 1998-2015 compared to that during 1979-1997, although the magnitude of shift in TC genesis location especially for the TC genesis longitude from these two datasets is less than that from the JTWC (Table 2). These are consistent well with previous studies on more TCs formed in the northwestern part of the WNP basin during La Niña and CP El Niño events compared to that during EP El Niño events (Wang and Chan 2002; Hong et al. 2011; Wang et al. 2013c), implying that such interdecadal changes of mean TC formation location is closely associated with the shifting ENSO and phase switch of the PDO.
Fig. 1 Time series of the JuneAugust (JJA) TC frequency (in black) over the main development region of the WNP $\left(5-25^{\circ} \mathrm{N}, 100-180^{\circ} \mathrm{E}\right)$, the Niño-3.4 index (in green) and PDO index (in blue) during 1979-2015. The symbol “*”, indicates the correlations are statistically significant at the 95\% confidence level

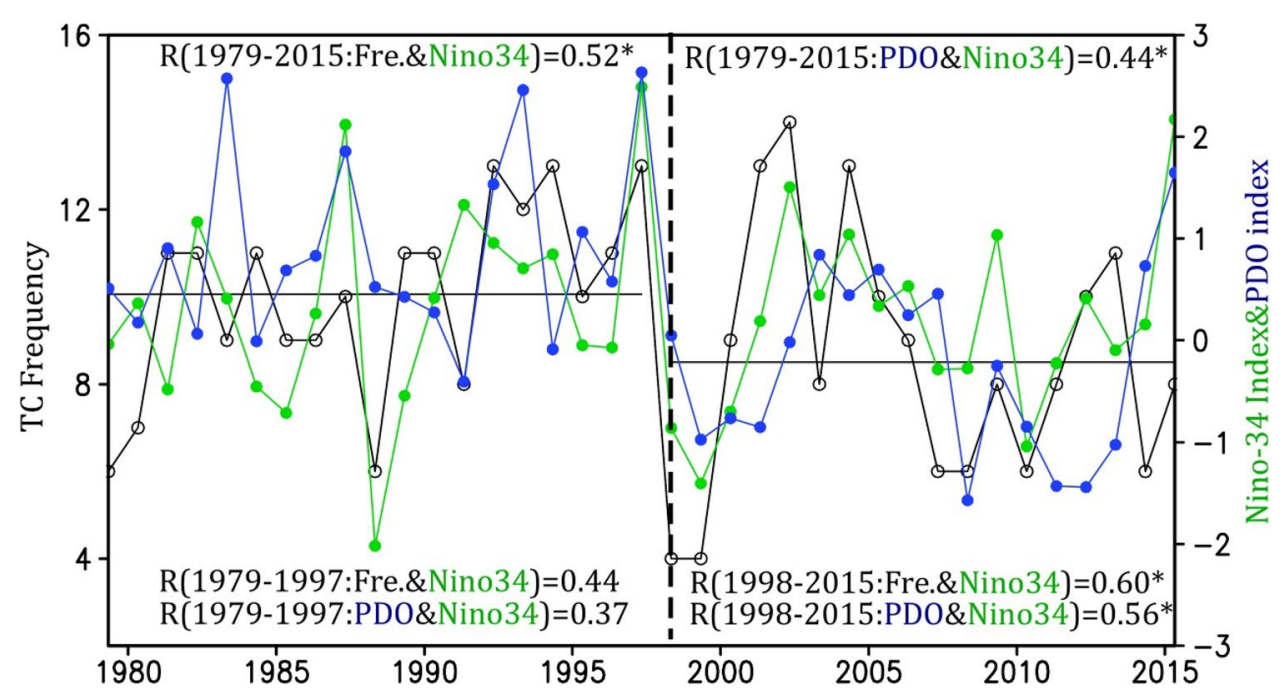

\begin{tabular}{llll}
\hline & $\begin{array}{l}\text { JTWC } \\
\text { Fre./Lat./Lon }\end{array}$ & $\begin{array}{l}\text { JMA } \\
\text { Fre./Lat./Lon }\end{array}$ & $\begin{array}{l}\text { CMA_STI } \\
\text { Fre./Lat./Lon }\end{array}$ \\
\hline $1979-2015$ & $9.4 / 16.5^{\circ} \mathrm{N} / 134.3^{\circ} \mathrm{E}$ & $9.6 / 16.9^{\circ} \mathrm{N} / 134.6^{\circ} \mathrm{E}$ & $9.5 / 16.9^{\circ} \mathrm{N} / 133.3^{\circ} \mathrm{E}$ \\
$1979-1997$ & $10.2 / 16.4^{\circ} \mathrm{N} / 135.6^{\circ} \mathrm{E}$ & $10.1 / 16.8^{\circ} \mathrm{N} / 134.9^{\circ} \mathrm{E}$ & $10.1 / 16.8^{\circ} \mathrm{N} / 133.7^{\circ} \mathrm{E}$ \\
$1998-2015$ & $8.50 / 16.7^{\circ} \mathrm{N} / 132.2^{\circ} \mathrm{E}$ & $9.0 / 16.9^{\circ} \mathrm{N} / 134.4^{\circ} \mathrm{E}$ & $8.9 / 17.1^{\circ} \mathrm{N} / 132.8^{\circ} \mathrm{E}$ \\
Diff & $-\mathbf{1 . 7} / 0.3^{\circ} /-\mathbf{3 . 4 0}^{\circ}$ & $\mathbf{1 . 1} / 0.10^{\circ} /-0.5^{\circ}$ & $-\mathbf{1 . 2}^{\circ} / 3^{\circ} / \mathbf{0 . 9}^{\circ}$ \\
\hline
\end{tabular}

The difference in bold is significant at a $95 \%$ confidence level
Table 2 Statistics of mean TC frequency, mean TC genesis latitude and longitude from the three best track datasets for the whole period (1979-2015) and the two sub-periods (1979-1979 and 1998-2015)

Table 3 Correlations of the JJA TC frequency over the MDR of the WNP basin from the three best track datasets respectively with Niño-3.4, Niño-3 and EMI for the whole period and the two sub-periods

\begin{tabular}{llll}
\hline & JTWC & JMA & CMA_STI \\
Niño-3.4/Niño-3/EMI & Niño-3.4/Niño-3/EMI & Niño-3.4/Niño-3/EMI \\
\hline $1979-2015$ & $\mathbf{0 . 5 2 * / 0 . 2 7 / 0 . 5 4 *}$ & $\mathbf{0 . 4 1} * / 0.17 / 0.54^{*}$ & $\mathbf{0 . 4 2 * / 0 . 1 6 / 0 . 5 8 *}$ \\
$1979-1997$ & $0.44 / 0.35 / 0.21$ & $0.26 / 0.16 / 0.23$ & $0.30 / 0.17 / 0.32$ \\
$1998-2015$ & $\mathbf{0 . 6 0} * / 0.24 / \mathbf{0 . 7 4} *$ & $\mathbf{0 . 5 7 * / 0 . 2 0 / 0 . 7 9 *}$ & $\mathbf{0 . 5 5 * / 0 . 1 6 / 0 . 8 1 *}$ \\
\hline
\end{tabular}

The correlation coefficients in bold with asterisk are significant at a $95 \%$ confidence level 


\subsection{Increased interannual relationship between ENSO and TCs}

All the correlations between the TC frequency from the three best track datasets and Niño-3.4 index during 1979-2015 are significant above the $95 \%$ confidence level (Table 3 ). However, this significant ENSO relationship with the TC number is due to the increased association between ENSO and the TC frequency after 1998. During the first epoch of 1979-1997, the correlation between them is insignificant at the $95 \%$ confidence level. In contrast, the correlation between them becomes significant at the $95 \%$ confidence level during the second epoch of 1998-2015.

To explore the association between two different ENSO flavors and the TC frequency, we compute the interannual correlations between the TC frequency and two ENSO flavors, i.e., CP ENSO events (represented by the EMI index) and EP ENSO events (represented by the Niño-3 index) for the whole and two sub-periods (Table 3). During 1979-2015, there is a significant correlation between EMI and TC frequency, while no significant correlation between Niño-3 index and TC frequency can be observed. It is therefore plausible that a regime shift in ENSO contributes to this significant correlation between ENSO and the TC frequency during the whole period 1979-2015. As expected, there is an interdecadal change of the interannual correlation between the TC frequency from the three datasets and EMI, while no apparent decadal change between the TC frequency and the Niño-3 index is found (Table 3). During 1979-1997, both the Niño-3 index and EMI insignificantly correlate to the TC frequency. However, the correlation between the TC frequency and Niño-3 index remains insignificant during 1998-2015; but the correlation between the TC frequency and EMI during 1998-2015 becomes significant. To further confirm these results, we also use the CP and EP ENSO indices based upon the regression-EOF analysis by Kao and $\mathrm{Yu}$ (2009) and Yu and Kim (2010). The almost identical results are found (figure not shown).

We further compute the spatial correlation map between the TC frequency and tropical SST (Fig. 2). A significant SST correlation is found over the CP region during 1998-2015. However, during 1979-1997 the SSTs in both the EP and CP regions do not show a significant correlation with the TC frequency. This suggests that the increased ENSO-TC relationship after 1998 is mainly due to the change of CP SST after 1998, also coinciding with a regime shift of ENSO and PDO phase switch. In other words, the increased occurrence of CP ENSO events and the cool PDO phase switch from the warm PDO phase after 1998 are responsible for the increased relationship between ENSO and TCs.

The relationships between the two ENSO flavors and mean TC genesis longitude are shown in Table 4. All the Niño-3.4, (a) $1998-2015$

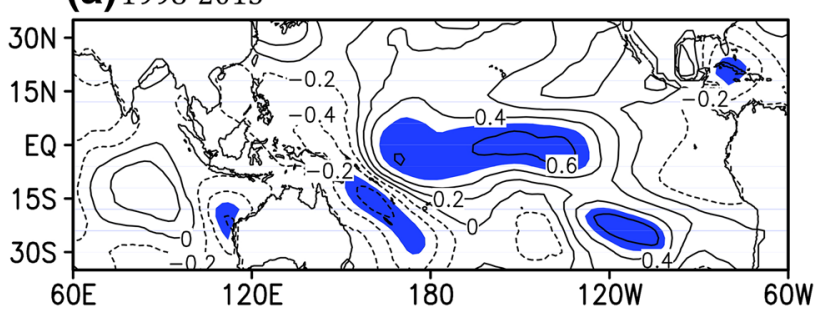

(b) $1979-1997$

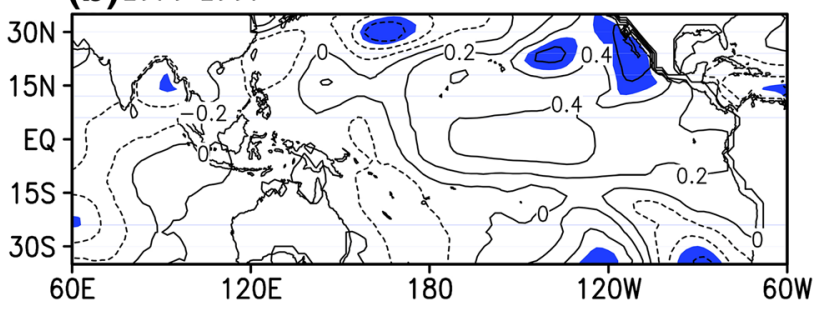

Fig. 2 Correlation of the June-August (JJA) TC frequency in the main development region of the WNP $\left(5-25^{\circ} \mathrm{N}, 100-180^{\circ} \mathrm{E}\right)$ and JJA sea surface temperature (SST) during (a) 1998-2015 and (b) 19791997. Shading in (a) and (b) indicates the correlations are significant at the $95 \%$ confidence level

Niño-3, and EMI are weakly correlated with mean TC genesis longitude used the three best track datasets over the whole period 1979-2015. It is further shown a consistent interdecadal change of all their relationships, with significant correlation between after 1998 and weak correlation before 1998. In other words, a stronger relationship between both the CP and EP SSTs and mean TC genesis longitude after 1998 can be found, indicating that the Pacific climate shift plays an important role in the change of mean TC genesis longitude. In contrast, no significant decadal change of interannual relationship between mean TC genesis latitude and both Niño-3 and Niño-3.4 indices can be found, while an obvious interdecadal change of interannual relationship between EMI and mean TC genesis latitude can be seen from the three datasets (Table 5). EMI are weakly correlated with mean TC genesis latitude during 1979-1997. During 1998-2015, however, the mean TC genesis latitude significantly correlates to the EMI. It implies an important role of CP ENSO events in controlling the mean TC genesis longitude. In summary, the relationship between ENSO and TC genesis locations is closely associated with the Pacific climate switch and a regime shift in ENSO. Next we examine large-scale climate factors being responsible for the observed changes of TC activity in the WNP. In terms of these relationships between ENSO and the JJA TC activity used CMA and JMA datasets are almost identical to that used the JTWC data. Therefore, we only present the main results used the JTWC in the following section, unless otherwise specified. 
Table 4 Same as Table 3, except for the mean TC genesis longitude

\begin{tabular}{lclc}
\hline & JTWC & JMA & CMA_STI \\
& Niño-3.4/Niño-3/EMI & Niño-3.4/Niño-3/EMI & Niño-3.4/Niño-3/EMI \\
\hline $1979-2015$ & $0.29 / 0.18 / 0.33$ & $0.39 / 0.27 / 0.44$ & $0.32 / 0.22 / 0.32$ \\
$1979-1997$ & $-0.15 /-0.09 /-0.01$ & $0.01 / 0.03 / 0.14$ & $-0.11 /-0.10 /-0.13$ \\
$1998-2015$ & $\mathbf{0 . 6 7} * / \mathbf{0 . 5 1} * / \mathbf{0 . 5 3} *$ & $\mathbf{0 . 6 9} * / \mathbf{0 . 5 3} * / \mathbf{0 . 6 1} *$ & $\mathbf{0 . 6 7} * / \mathbf{0 . 5 5} * / \mathbf{0 . 6 2} *$ \\
\hline
\end{tabular}

Table 5 Same as Table 4, except for the mean TC genesis latitude.

\begin{tabular}{llll}
\hline & JTWC & JMA & CMA_STI \\
& Niño-3.4/Niño-3/EMI & Niño-3.4/Niño-3/EMI & Niño-3.4/Niño-3/EMI \\
\hline $1979-2015$ & $-\mathbf{0 . 5 2} * /-\mathbf{0 . 5 2} * /-0.35$ & $-\mathbf{0 . 6 2} * /-\mathbf{0 . 5 8} * /-0.34$ & $-\mathbf{0 . 5 6} * /-\mathbf{0 . 4 8} * /-0.17$ \\
$1979-1997$ & $-\mathbf{0 . 5 0} /-\mathbf{0 . 5 5} /-0.02$ & $-\mathbf{0 . 5 9} /-\mathbf{0 . 6 6} /-0.01$ & $-\mathbf{0 . 4 7} * /-\mathbf{0 . 5 9} * / 0.09$ \\
$1998-2015$ & $-\mathbf{0 . 5 4} /-\mathbf{0 . 4 9} /-\mathbf{0 . 6 7} *$ & $-\mathbf{0 . 6 7} * /-\mathbf{0 . 4 8} * /-\mathbf{0 . 6 8} *$ & $\mathbf{- 0 . 6 8} /-0.46 /-0.43$ \\
\hline
\end{tabular}

\section{Large-scale climate factors associated with the changes of TC activity}

In this section, we analyze large-scale environmental climate factors that may cause the changes of TC activity observed during 1979-2015 in the WNP. For the reduction of the TC number after 1998, we examine environment composite differences between the periods of 1979-1997 and 1998-2015. For the increased interannual relationship between ENSO and TCs, we compare the ENSO correlation maps with environmental variables between two sub-periods.

\subsection{Longer-term changes of environmental variables}

We first look at the differences of SST and 850-hPa wind anomalies between two periods of 1979-1997 and 1998-2015 (Fig. 3). The periods of 1979-1997 and 1998-2015 are the warm and cold phases of the PDO, respectively. Therefore, during 1998-2015, the warm SST anomalies are located in the western Pacific and easterly wind anomalies are found in the tropical western Pacific (Fig. 3a). Additionally, strengthening of the North Pacific subtropical high after 1998 can be inferred (Fig. 3a). In fact, we use the 1530 and 1560 geopotential height lines at $850 \mathrm{hPa}$ to represent the subtropical-high intensity following Lin et al. (2015) and find a consistent strengthening of subtropical-high during the recent decades (figure not shown). The opposite patterns are observed during the period of 1979-1997 (Fig. 3b). As suggested by previous studies (Maue 2011; Liu and Chan 2013; Zhao et al. 2016; Hsu et al. 2014; Zhao and Wang 2016), significantly different impacts of different SSTA patterns on tropical Indo-Pacific climate anomalies have been found. One would expect that the SSTA pattern associated with the PDO phase switch may change large-scale variables that in turn affect the reduction of TC (a) $1998-2015$ (SSTA\&850hPa winds)

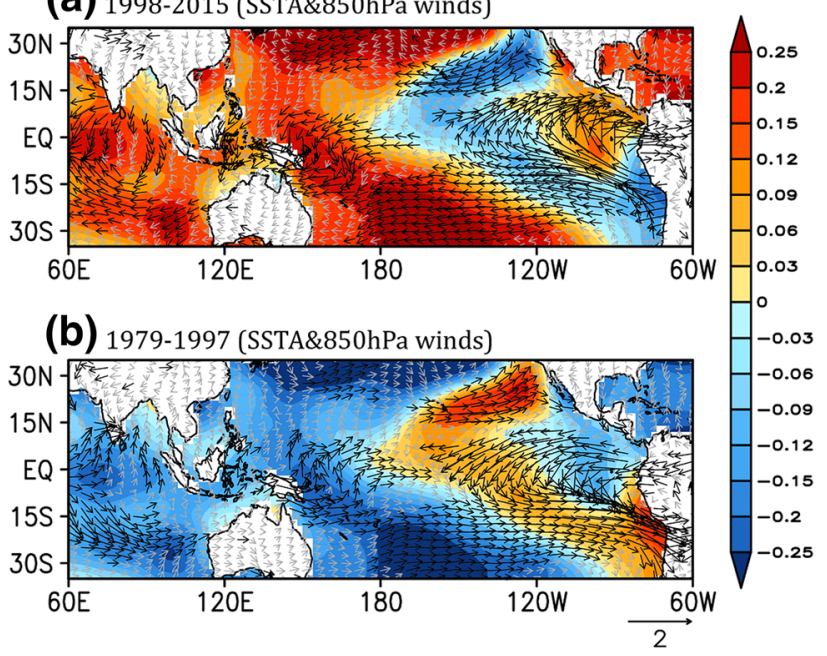

Fig. 3 Sea surface temperature anomaleis (SSTAs) and $850 \mathrm{hPa}$ wind anomalies during (a) 1998-2015 and (b) 1997-1997 with respect to the whole period 1979-2015. Vectors in black color during indicate that the differences are significant at the $95 \%$ confidence level

activity in the WNP since 1998. The SST patterns associated with the PDO phase switch may change other large-scale variables that in turn affect TC activity in the WNP.

The SST and wind distributions are associated with the changes of low-level relative vorticity and tropospheric vertical wind shear, both of these two large-scale variables can affect TC activity in the WNP (Fig. 4). For example, an increase of the low-level cyclonic vorticity is favorable for the TC development of convection and intensification by reducing the local Rossby radius of deformation and then focusing the convective heating locally (Chen et al. 2006). An enhanced vertical wind shear generally inhibits the TC development by advecting the heating and moisture away from the convention center (DeMaria 1996). Over the WNP especially over its eastern part, the decreased low-level 

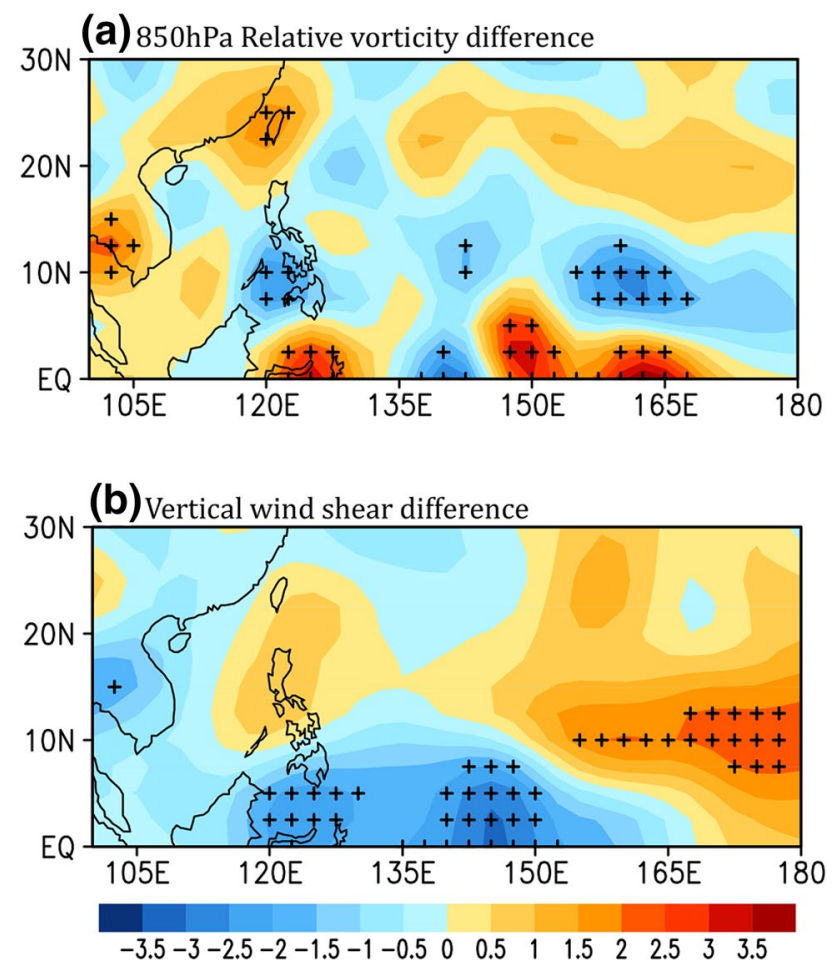

Fig. 4 Differences of $\mathbf{a} 850 \mathrm{hPa}$ relative vorticity and $\mathbf{b}$ vertical wind shear between 1998 and 2015 and 1979-1997 (1998-2015 minus 1979-1997). "+" sign indicates that the differences are significant at the $95 \%$ confidence level

relative vorticity (Fig. 4a) and increased vertical wind shear (Fig. 4b) are evidently found during 1998-2015 compared to 1979-1997. These two factors are unfavorable for TC genesis during 1998-2015 especially for the southeastern region of the WNP (Gray 1968; Emanuel and Nolan 2004). Over the southeastern region of the WNP basin, $\left[5^{\circ} \mathrm{N}-25^{\circ} \mathrm{N}\right.$, $140^{\circ} \mathrm{E}-180^{\circ} \mathrm{E}$ ], $3.6 \mathrm{TCs}$ each year on average occur during the first sub-period and 2.1 TCs form during the second subperiod. Their difference $1.5 \mathrm{TCs}$ is significant at a $95 \%$ confidence level, which accounts for $75 \%$ of the total differences of total WNP TC frequency between the two sub-periods. These two large-scale environmental factors may explain the reduction of the JJA TC frequency observed in the WNP during 1998-2015 in comparison with 1979-1997.

We also analyze the $600 \mathrm{hPa}$ relative humidity from the NCEP-2 during two periods and find that the humidity change does not contribute to the reduction of the JJA TC frequency during 1998-2015 (not shown). In fact, the mid-level relative humidity from the other reanalysis products shows an inconsistent relationship with the JJA TC frequency. One of the possible reasons is the uncertainty of the mid-level relative humidity in reanalysis datasets (Hodges et al. 2011; Vergados et al. 2014) and thus the role of the mid-level relative humidity in contributing to the reduction of TC frequency after 1998 needs more detailed observational analyses and numerical simulations.

In summary, the decreased low-level relative vorticity (Fig. 4a) and increased vertical wind shear (Fig. 4b) should be results of a shifting ENSO and Pacific climate shift. The SSTA pattern as shown in Fig. 3a during 1998-2015 is the similar to the Mega La Niña-like pattern described in Wang et al. (2013a). In Wang et al. (2013a), the Mega-ENSO index was computed as the SST difference between the western Pacific K-shape area and eastern Pacific triangle to quantify the characteristic variations of the Pacific SST. Such the Mega-ENSO index is similar to ENSO but with a larger spatial scale and a longer timescale. The Mega-ENSO is a multi-time-scale index. Details on the Mega-ENSO index can be found in Wang et al. (2013a). Associate with such Mega La Niña-like decadal phenomena, the reduction of vertical wind shear and the corresponding changes of lower-upper level winds have been documented due to the strengthening of North Pacific subtropical high and easterly trade wind (Wang et al. 2013a; Kosaka and Xie 2013; England et al. 2014; Lin and Chan 2015). In addition to impacts of the Mega La Niña-like pattern, how the shifting ENSO affects the environmental factors on the interdecadal time scale remains unclear. More analyses on the respective contributions of the shifting ENSO and Mega La Niña-like pattern to the increased vertical wind shear and decreased low-level vorticity after 1998 should be needed in a future study.

\subsection{Changes of interannual relationship between environmental variables and TCs}

Section 3 shows that the increased interannual relationship between ENSO and TCs after 1998 is largely due to the change of CP SST after 1998. It is thus expected that CP ENSO events change atmospheric variables which in turn affect TC activity in the WNP. Figure 5a, b compare the EMI correlation maps with $850 \mathrm{hPa}$ winds for two periods. The pronounced low-level westerly winds extend to the dateline, resulting in a significant intensified cyclonic circulation over the WNP during 1998-2015 compared to that during 1979-1997 (Fig. 5a, b). In the upper level of the troposphere, an anticyclonic correlation map can be found over the WNP during 1998-2015. These types of atmospheric circulation patterns increase the relationship between ENSO and TCs after 1998. Indeed, the relationship between the winds and the TC frequency during two periods is very similar to the correlation maps of EMI and winds (Figs. 5c, d, 6c, d). All of these suggest that a regime shift in ENSO changes atmospheric circulation patterns and then affects its association with TCs.

Associated with the atmospheric circulation changes, the changes of vertical wind shear and mid-level relative 
(a) $1998-2015$ (850hPa winds corr. EMI)

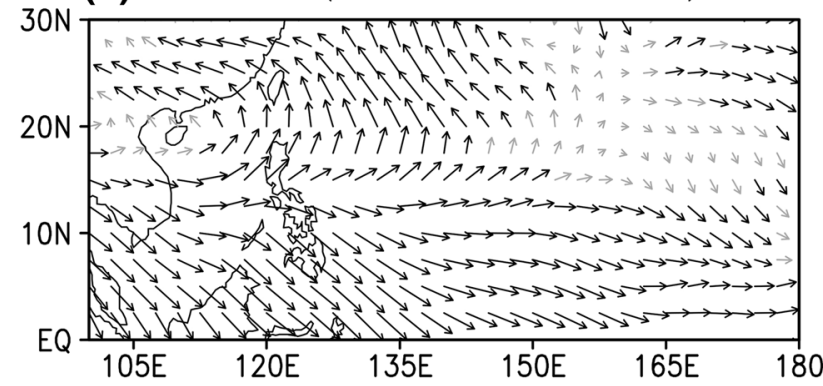

(b) $1979-1997$ (850hPa winds corr. EMI)

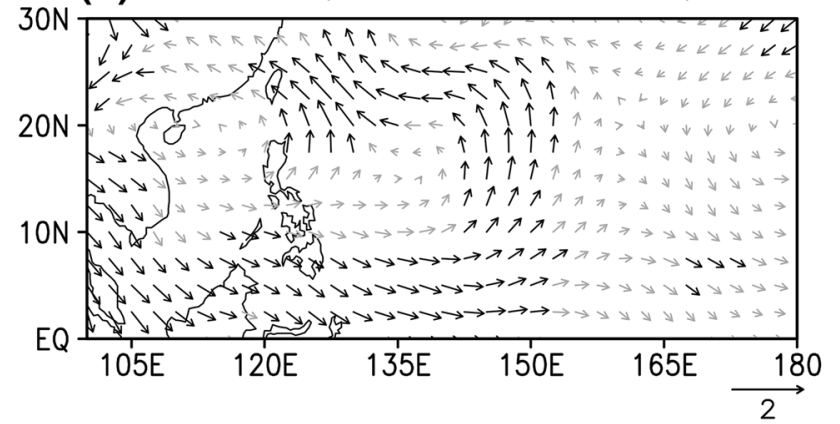

Fig. 5 Correlation between El Niño Modoki index (EMI) and $850 \mathrm{hPa}$ winds during a 1998-2015 and b 1979-1997, and correlation between the JJA TC frequency and $850 \mathrm{hPa}$ winds during c

(a) $1998-2015$ (200hPa winds corr. EMI)

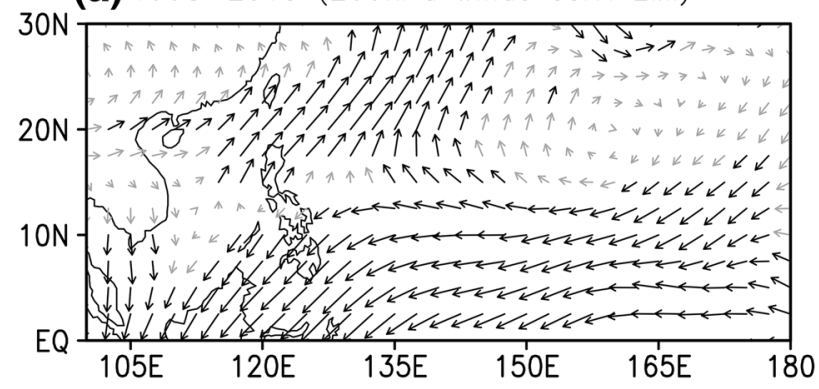

(b) $1979-1997$ (200hPa winds corr. EMI)

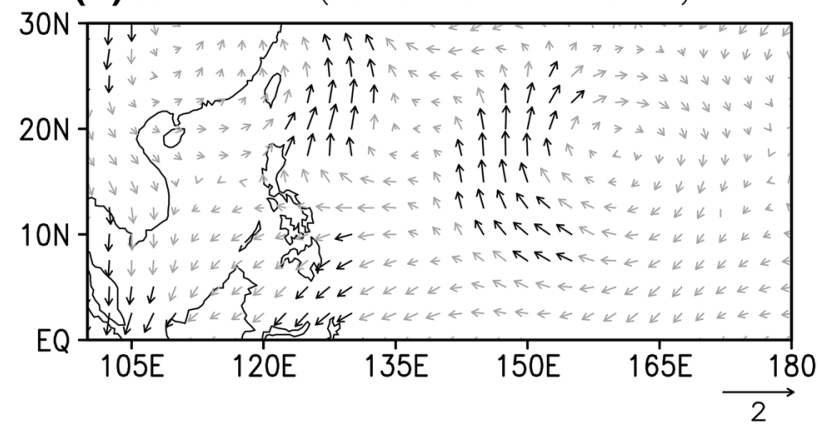

Fig. 6 Correlation between El Niño Modoki index (EMI) and $200 \mathrm{hPa}$ winds during a 1998-2015 and b 1979-1997, and correlation between the JJA TC frequency and $200 \mathrm{hPa}$ winds during $\mathbf{c}$
(C) $1998-2015$ (850hPa winds corr. TC Frequency)

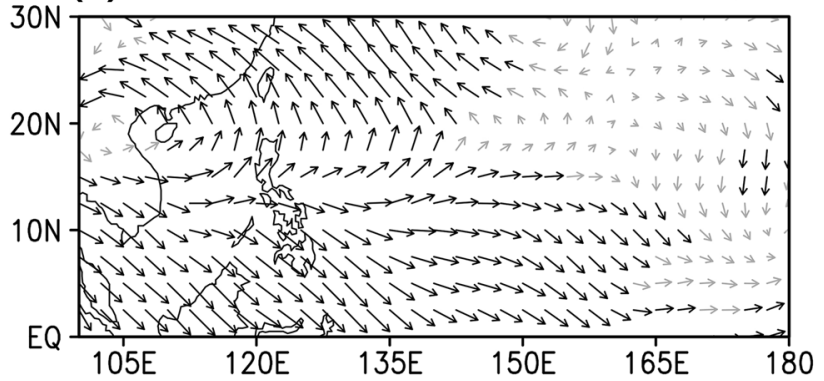

(d) 1979-1997 (850hPa winds corr. TC Frequency)

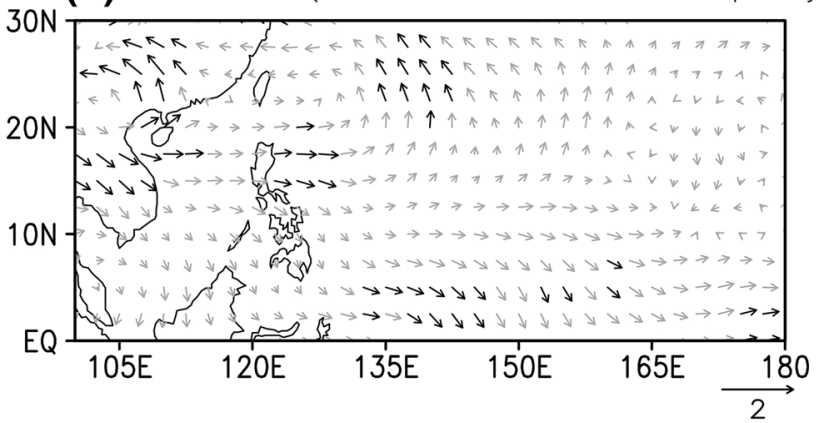

1998-2015 and d 1979-1997. Vectors in black during indicate that the correlations are significant at the $95 \%$ confidence level

(c) $1998-2015$ (200hPa winds corr. TC Frequency)

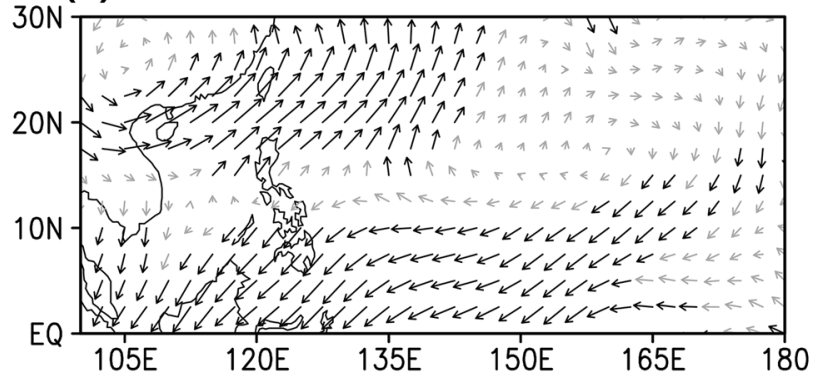

(d) 1979-1997 (200hPa winds corr. TC Frequency)

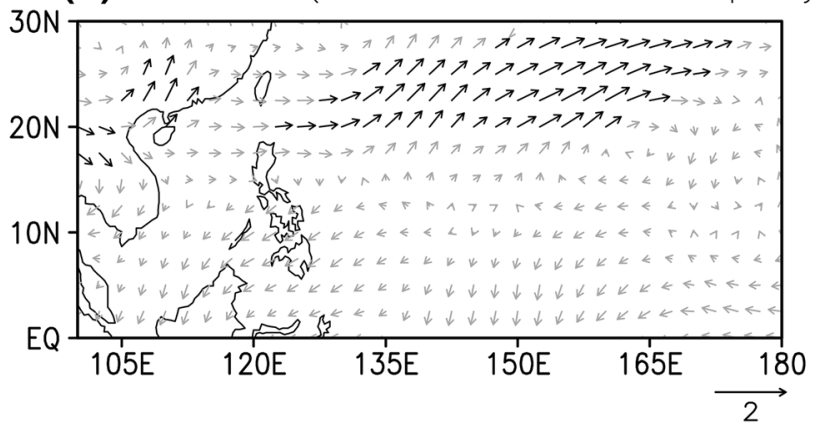

1998-2015 and d 1979-1997. Vectors in black during indicate that the correlations are significant at the $95 \%$ confidence level 
humidity are important for the increased interannual relationship between ENSO and TCs after 1998. The correlation maps of vertical wind shear and relative humidity with the EMI index and TC frequency for two periods of 1998-2015 and 1979-1997 are shown in Figs. 7 and 8. The correlation patterns are similar for two periods of 1998-2015 and 1979-1997; however, the stronger and more significant magnitudes appear during 1998-2015. The stronger and more significant vertical wind shear and mid-level relative humidity explain the increased interannual relationship between ENSO and TCs during 1998-2015. The correlation maps of the TC frequency with vertical wind shear and $600 \mathrm{hPa}$ relative humidity during two periods show a similar result (Figs. 7c, d, 8c, d). In short, more CP El Niño and La Niña events associated with the PDO phase shifting to a cool state after the late 1990s increase their associations of vertical wind shear and humidity with TCs, and result in the increased interannual relationship between ENSO and TCs after 1998. Such environmental variables with other reanalysis datasets are also checked and the similar and stronger relationships between these environmental factors and EMI/ TCs after 1998 are also found (figure not shown). Additionally, it is readily found that the Mega La Niña-like pattern after 1998 plays substantial contributions to the increased ENSO-TC relationship based upon the correlation maps between the environmental factors and Mega ENSO index computed following Wang et al. (2013a). For example, the correlation map between Mega-ENSO index and vertical wind shear shows a somewhat similar pattern as the correlation map between EMI and vertical wind shear since 1998, as shown in Figs. 7 and 9. The pattern correlation between them is 0.68 during the second sub-period, while only 0.21 during the first sub-period 1979-1997. The pattern correlation 0.6 represents a reasonable lower limit for the significance as suggested by Wilks (2006). In summary, the increased ENSO-TC interannual relationship is also the synergetic effect of a shifting ENSO and Pacific climate shift.

\section{Summary and discussion}

Since ENSO is the largest interannual climate phenomenon on earth, it has been extensively studied during the past decades [see the recent ENSO overview by Wang et al. (2016)]. In particular, two types of ENSO events accompanied with the Pacific climate shift were paid attention in the recent years: Eastern Pacific (EP) and Central Pacific (CP) ENSO events. By their names, EP ENSO events occur with maximum SST anomalies in the tropical EP, whereas CP ENSO events are with maximum SST anomalies in the tropical CP. Previous studies have shown that more CP El Niño and La Niña events have occurred since the recent decades in association with the climate shift (Ashok et al. 2007; Kao and Yu 2009; Lee and McPhaden 2010; Yu et al. 2012; Cai (a) 1998-2015 (Shear corr. EMI)

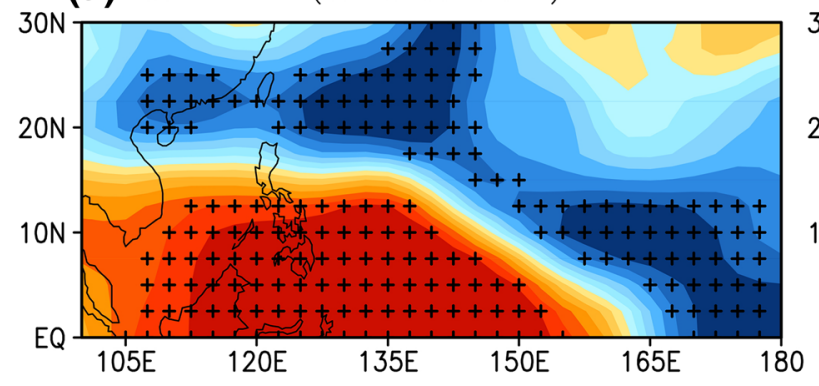

(b) $1979-1997$ (Shear corr. EMI)

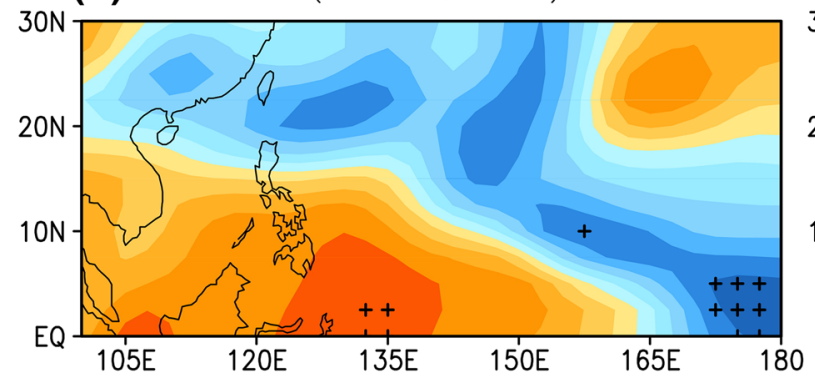

Fig. 7 Correlation between El Niño Modoki index (EMI) and vertical wind shear during a 1998-2015 and b 1979-1997, and correlation between the JJA TC frequency and vertical wind shear during $\mathbf{c}$ (c) 1998-2015 (Shear corr. TC Frequency)

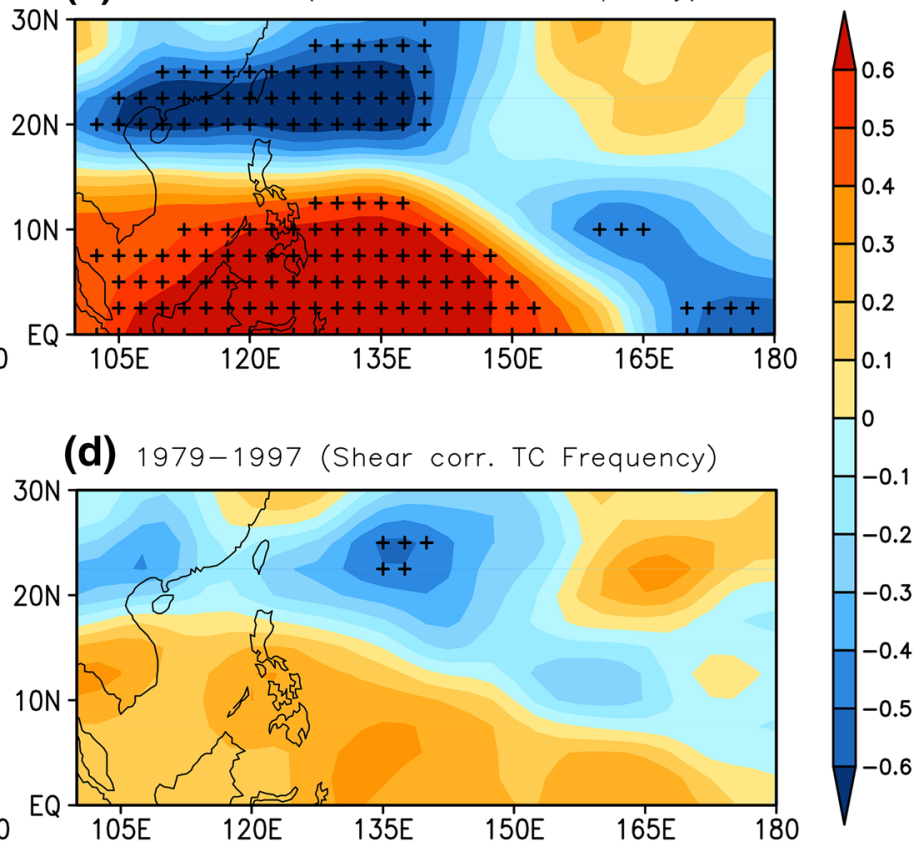

1998-2015 and d 1979-1997. "+" Sign indicates that the correlations are significant at the $95 \%$ confidence level 
(a) 1998-2015 (600hPa RH corr. EMI)

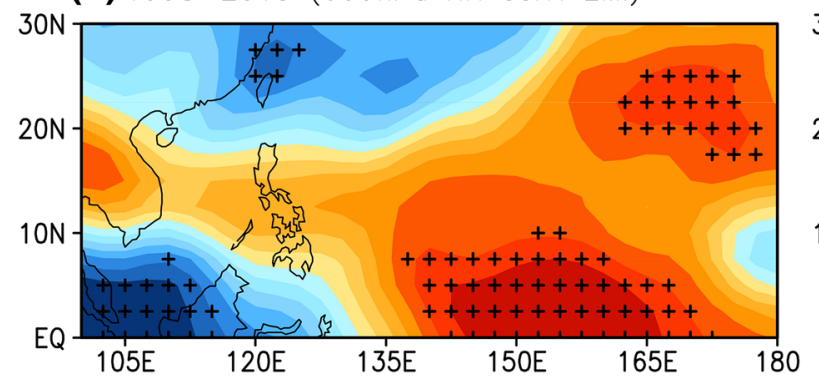

(b) $1979-1997$ (600hPa RH corr. EMI)

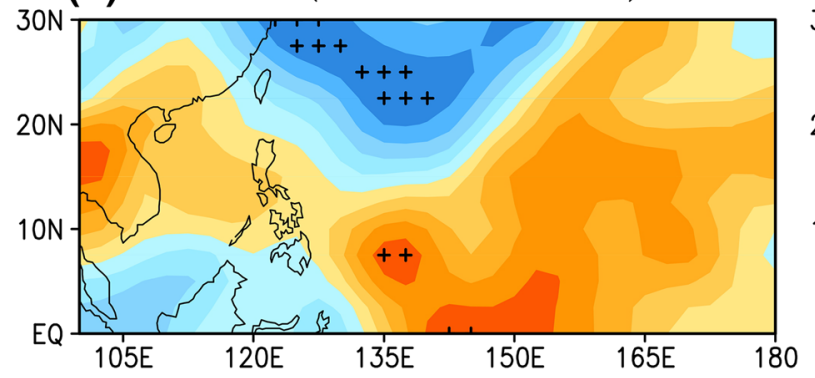

Fig. 8 Correlation between El Niño Modoki index (EMI) and $600 \mathrm{hPa}$ relative humidity during a 1998-2015 and b 1979-1997, and correlation between the JJA TC frequency and $600 \mathrm{hPa}$ relative

et al. 2015). In this paper, we found that the shifting ENSO and Pacific climate shift after the late 1990s increase the

(a) 1998-2015 (Shear corr. Mega-ENSO index)

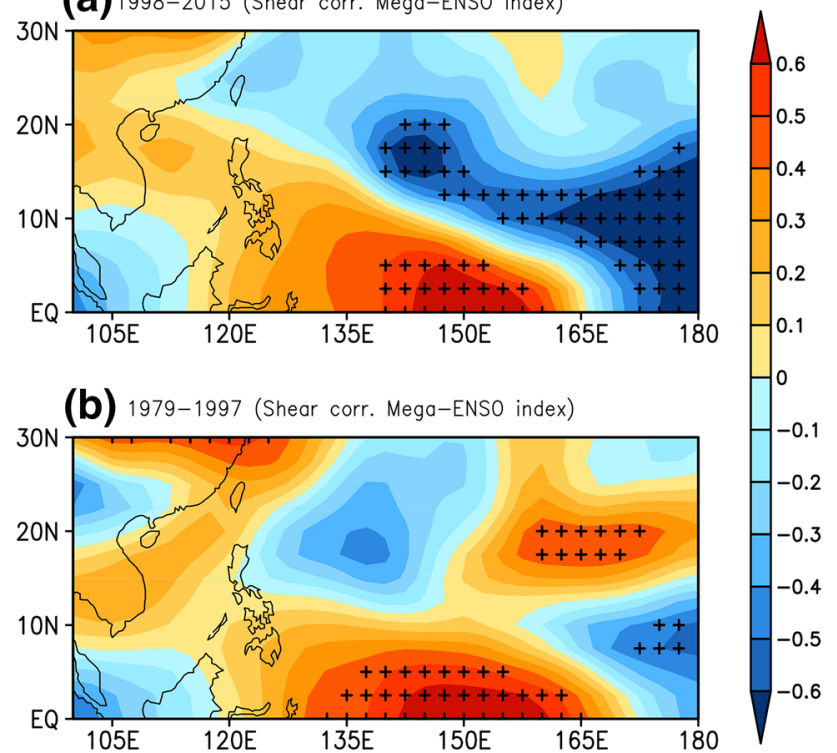

Fig. 9 Correlation between Mega ENSO index developed by Wang et al. (2013a) and vertical wind shear during a 1998-2015 and b 1979-1997. "+" Sign indicates that the correlations are significant at the $95 \%$ confidence level (c) $1998-2015$ (600hPa RH corr. TC Frequency)
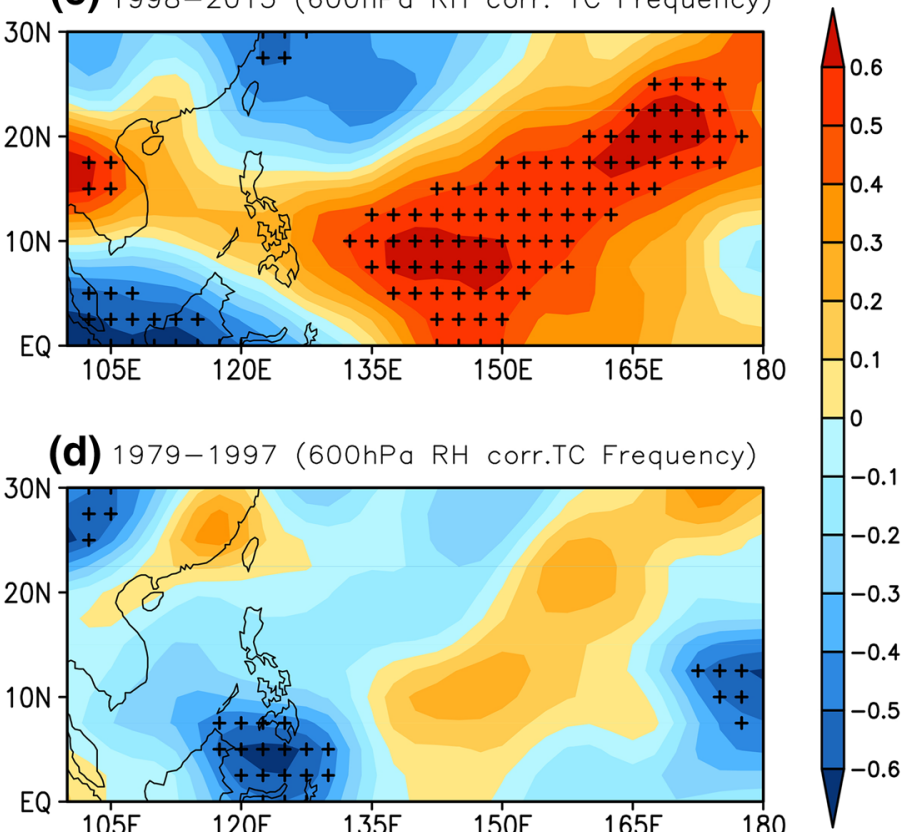

humidity during c 1998-2015 and d 1979-1997. “+” Sign indicates that the correlations are significant at the $95 \%$ confidence level

interannual relationship between ENSO and TC activity in the WNP.

We use the data of the satellite era to show that 1998 is an important year for shifting or changing the relationships between ENSO and TC activity in the WNP. Two major feature changes are observed around 1998: (1) a stronger interannual relationship between ENSO and TCs after 1998 and (2) the sharp reduction of the TC number after 1998. On interannual time scale, we found that the SST distribution over the CP region associated with the cool PDO phase is responsible for the stronger interannual relationship between ENSO and TCs after 1998. Although both the EP and CP ENSO's SST anomalies can affect the changes of vertical wind shear, low-level/upper-level winds and mid-level relative humidity, these variable changes are more significant during 1998-2015 than 1979-1997. The more significant changes of vertical wind shear and mid-level relative humidity induced by CP ENSO events during 1998-2015 significantly increase the interannual relationship between ENSO and TCs during 1998-2015.

On a longer or decadal time scale, the TC number shows an abrupt reduction after 1998. The averaged TC number during 1979-1997 is significantly larger than that during 1998-2015. This is because the periods of 1979-1997 and 1998-2015 are associated with the warm and cold phases of the PDO, respectively. Therefore, during 1998-2015, the warm SST anomalies are located in the western Pacific and 
easterly wind anomalies are found in the tropical western Pacific. The opposite patterns are observed during the period of 1979-1997. The SST distributions in the tropical western Pacific associated with the PDO do not directly contribute to the reduction of the TC number after 1998. However, the PDO-like SST-induced wind changes decrease low-level relative vorticity and increase vertical wind shear in the WNP during 1998-2015 compared to 1979-1997, thus resulting in the TC reduction during 1998-2015.

The feature changes of the TC number in the WNP also apply to the TC genesis location. The TC genesis location in the WNP shows similar interannual and decadal changes in 1998. In particular, the TC genesis location during 1998-2015 has a northwestward shift compared to that during 1979-1997. During 1998-2015, there is a significant westward shift and moderate northward displacement of TC genesis locations, which is mainly due to the changes of CP and EP SST distribution. As suggested by previous studies (Lander 1994; Wang and Chan 2002; Camargo and Sobel 2005; Wang et al. 2013; Zhao 2016), more TCs formed over the northwestern part of WNP basin during La Niña years and CP El Niño events compared to that during EP El Niño events, and thus such northwestward shift of mean TC genesis location is well consistent with more La Niña events and CP El Niño events occurs during 1998-2015. To further clarify the contribution from the ENSO transition itself, we also computed the interannual correlation only for the selected ENSO years as shown in Table 1. Interannual correlation between the total 23 ENSO years and the corresponding TC frequency is significant with the correlation coefficient 0.57 . When the total 23 ENSO years was divided in to the two sub-periods: before 1998 and after 1998, it is found that the interannual correlation between them (total 10 years) is 0.53 , which is not statistically significant at the 95\% confidence level. In contrast, a significant interannual correlation between them (total 13 years) can be found at the $95 \%$ confidence level after 1998 with the correlation coefficient 0.74 . These imply that the interdecadal change of relationship between ENSO and TC frequency as suggested in this study is largely due to the changes of ENSO regime shifts and its association with TC frequency. Additionally, ENSO-associated TC frequency also shows a significant reduction since 1998 with the difference of 1.6 TCs each year on average. The ENSO-associated TC genesis longitude shows a significantly westward shift of 4.6 degree since 1998. These are consistent well with the studies on the interdecadal changes of WNP TC activity in 1998 (Liu and Chan 2013, Hsu et al. 2014; Zhao and Wang 2016; Huangfu et al. 2017). In summary, the interdecadal changes of mean TC genesis location is largely due to the synergistic effect of shifting ENSO and Pacific climate switch.

Associated with the interdecadal shift of ENSO-TC interannual correlation occurs in 1998, the interannual correlation between PDO and ENSO during the boreal summer also shows an interdecadal shift (Fig. 1). During the whole period 1979-2015, a significant interannual correlation between the PDO and ENSO with the correlation coefficient 0.44 can be found. Further analyses suggested that such the significant interannual correlation between them during the whole period 1979-2015 is mainly due to the enhanced interannual correlation between them during the recent decades 1998-2015 with the correlation coefficient 0.56 . It's possible that the interdecadal change of the PDO-ENSO interannual correlation has an impact on the ENSO-TC relationship during the boreal summer.

This paper presents the results of TC activity in the WNP MDR region $\left(5-25^{\circ} \mathrm{N}, 100-180^{\circ} \mathrm{E}\right)$ during the summer of JJA. In JJA, 10 TCs each year on average accounts for about $40 \%$ of annual total TC counts over the WNP basin. Meanwhile, a significant decrease of JJA TCs can be observed since 1998. More importantly, a significantly enhanced relationship between ENSO and JJA TC frequency can be found since 1998. Although the results are sensitive to the region and season, major features and conclusions do not change with the focused region and time. We repeat the plots of Fig. 1 with the TC counts over the extended region of the WNP $\left(0-30^{\circ} \mathrm{N}, 100-180^{\circ} \mathrm{E}\right)$ and the seasons of June-August, May-November, and JuneOctober (Fig. 10). During 1979-2015, all cases except June-August show that the correlations between the TC number and Niño-3.4 index are below the $95 \%$ confidence level. This is consistent with previous studies that ESNO insignificantly correlates with the total TC frequency (e.g., Chan 1985; Chan and Shi 1996; Chen et al. 1998; Wang and Chan 2002; Camargo and Sobel 2005). However, all of three cases show a significant increase of ENSO-TC correlations after 1998. For the summer (JJA) case, the ENSO-TC correlation shows an interdecadal change, with weak correlation 0.20 before 1998 and significant correlation 0.54 after 1998. Although both changes of ENSO-TC correlation over the May-November or June-October are smaller than that over the JJA, the correlations between them show a remarkable interdecadal change as that during JJA. Following Fisher (1921), the statistical differences of the correlation coefficients during the two subperiods over the extended seasons (e.g., May-November or June-October) are significant. These indicate that the change of ENSO-TC relationship after 1998 is a robust result. Such magnitude of changes in relationship over different seasons may be associated with the possible modulation of the shifting ENSO and Pacific climate switch and needs further investigations. This study has an important implication for TC outlooks based on climate predictions and projections. If climate models can correctly predict the types of ENSO events (CP or EP events), we are in a 

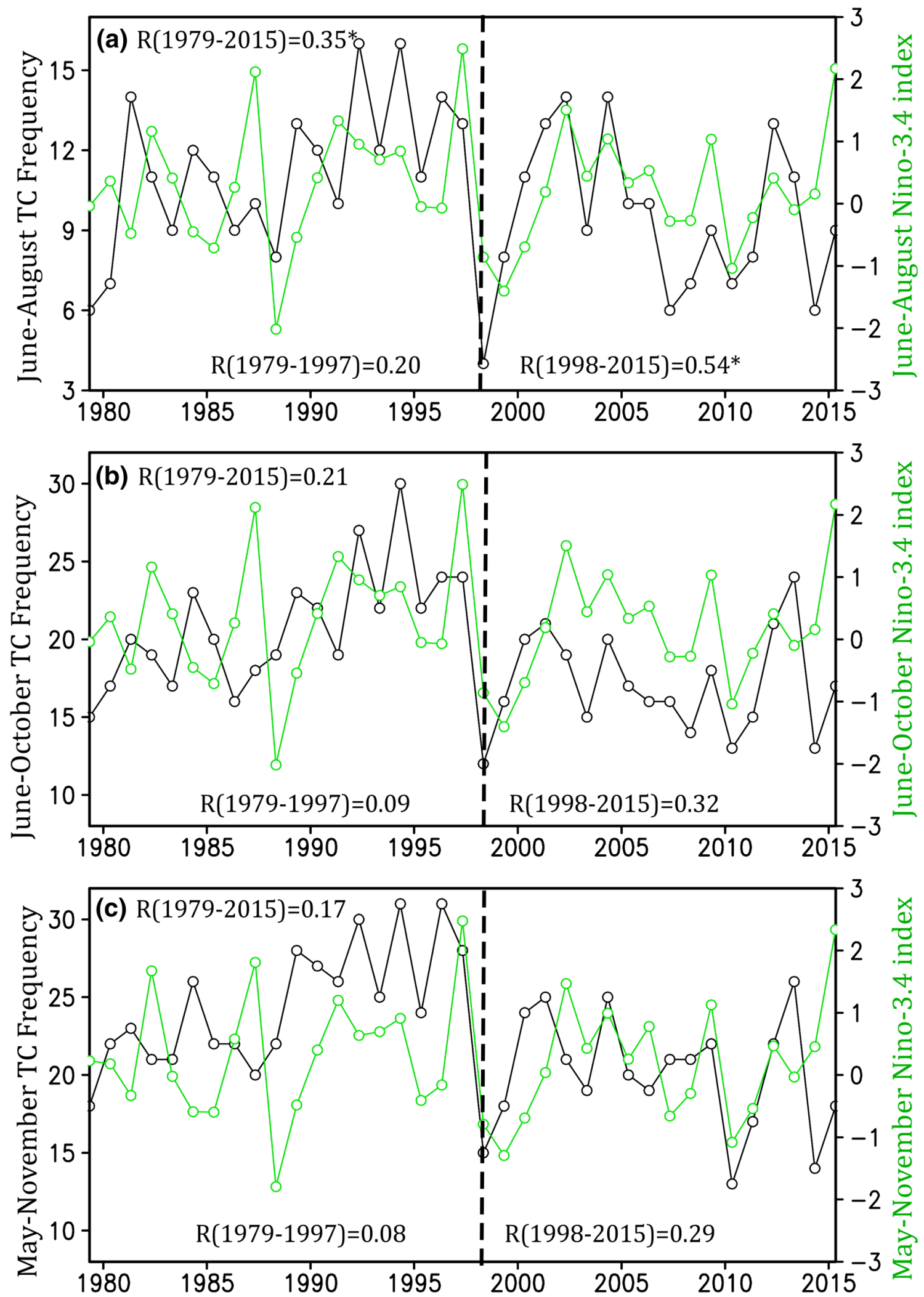

Fig. 10 Time series of a June-August, b June-October and c MayNovember TC frequency in the WNP region of $\left(0-30^{\circ} \mathrm{N}, 100-180^{\circ} \mathrm{E}\right)$ and Niño-3.4 index during 1979-2015. The symbols "**" indicate that the correlation are statistically significant at the $95 \%$ confidence level, respectively 
better position to know the relationship between ENSO and TCs in the WNP (Wang et al. 2013b, 2016; Han et al. 2016). Similarly, if climate model can project future types of ENSO events under global warming, it will help us understand future TC activity in the WNP. Meanwhile, this study is helpful to clarify the relationship between TC genesis and frequencies over the WNP basin.

Acknowledgements We thank reviewers for their comments and suggestions which help improve the manuscript. This research was jointly supported by the National Natural Science Foundation of China (41675072, 41475091, 41731173, and 41730961), the Qing Lan Project of Jiangsu Province (R2017Q01), the Natural Science Foundation for Higher Education Institutions in Jiangsu Province (12KJA170002), the Leading Talents of Guangdong Province Program, the Pioneer Hundred Talents Program of the Chinese Academy of Sciences, the National Basic Research Program of China (2015CB452803), the National Program on Global Change and Air-Sea Interaction (GASI-IPOVAI-04), and the Priority Academic Program Development of Jiangsu Higher Education Institutions (PAPD).

Open Access This article is distributed under the terms of the Creative Commons Attribution 4.0 International License (http://creativeco mmons.org/licenses/by/4.0/), which permits unrestricted use, distribution, and reproduction in any medium, provided you give appropriate credit to the original author(s) and the source, provide a link to the Creative Commons license, and indicate if changes were made.

\section{References}

Ashok K, Behera S, Rao AS, Weng HY, Yamagata T (2007) El Niño Modoki and its teleconnection. J Geophys Res 112:C11007. https:// doi.org/10.1029/2006JC003798

Cai W et al (2015) ENSO and greenhouse warming. Nat Clim Change 5:849-859

Camargo SJ, Sobel AH (2005) Western North Pacific tropical cyclone intensity and ENSO. J Clim 18:2996-3006

Cao X, Chen SF, Chen GH, Wu RG (2016) Intensified impact of Northern Tropical Atlantic SST on Tropical cyclogenesis frequency over the Western North Pacific after the late 1980s Adv Atmos Sci 33(8):919-930. https://doi.org/10.1007/s00376-016-5206-z

Chan JCL (1985) Tropical cyclone activity in the Northwest Pacific in relation to El Niño/Southern Oscillation phenomenon. Mon Weather Rev 113:599-606

Chan JCL (2000) Tropical cyclone activity over the western North Pacific associated with El Niño and La Niña events. J Clim 13:2960-2972

Chan JCL (2005) Interannual and interdecadal variations of tropical cyclone activity over the western North Pacific. Meteorol Atmos Phys 89:143-152. https://doi.org/10.1007/s00703-005-0126-y

Chan JCL (2008) Decadal variations of intense typhoon occurrence in the western North Pacific. Proc R Soc A 464:249-272

Chan JCL, Shi J (1996) Long-term trends and interannual variability in tropical cyclone activity over the western North Pacific. Geophys Res Lett 23:2765-2767

Chen G, Tam CY (2010) Different impacts of two kinds of Pacific Ocean warming on tropical cyclone frequency over the western North Pacific. Geophys Res Lett 37:L01803. https://doi. org/10.1029/2009GL041708

Chen GTJ, Wang CC, Lin LF (2006) A Diagnostic Study of a Retreating Mei-Yu Front and the Accompanying Low-Level Jet Formation and Intensification. Monthly Weather Rev 134(3):874-896
Chen T-C, Weng S-P, Yamazaki N, Kiehne S (1998) Interannual variation in the tropical cyclone formation over the western North Pacific. Mon Weather Rev 126:1080-1090

Choi YK, Ha K-J, Ho C, Chung C (2015) Interdecadal change in typhoon genesis conditions over the western North Pacific. Clim Dyn 45:3243-3255

Chu PS (2002) Large-Scale Circulation Features Associated with Decadal Variations of Tropical Cyclone Activity over the Central North Pacific. J Clim 15(18):2678-2689

Chu PS, Zhao X (2004) Bayesian change-point analysis of tropical cyclone activity: the Central North Pacific case. J Clim 17:4893-4901

DeMaria M (1996) The Effect of Vertical Shear on Tropical Cyclone Intensity Change. J Atmo Sci 53(14):2076-2088

Emanuel KA, Nolan DS (2004) Tropical cyclone activity and the global climate system. Preprints, 26th Conf. on Hurricanes and Tropical Meteorology, Miami, FL, Amer. Meteor. Soc., 10A.2

England MH, McGregor S, Spence P, Meehl GA, Timmermann A, Cai W, Gupta AS, McPhaden MJ, Purich A, Santoso A (2014) Recent intensification of wind-driven circulation in the Pacific and the ongoing warming hiatus. Nat Clim Change 4:222-227

Fisher RA(1921) On the "probable error" of a coefficient of correlation deduced from a small sample., Metron, 1:1-32

Gray WM (1968) Global view of the origin of tropical disturbances and storms. Mon Wea Rev 96:669-700

Han R, and co-authors (2016) An assessment of multimodel simulations for the variability of Western North Pacific tropical cyclones and its association with ENSO. J Clim 29:6401-6423

He HZ, Yang J, Wu LG, Gong DY, Wang B, Gao MN (2017) Unusual growth in intense typhoon occurrences over the Philippine Sea in September after the mid-2000s. Clim Dyn 48:1893-1910

Hodges KI, Lee RW, Bengtsson L (2011) A comparison of extratropical cyclones in recent reanalyses ERA-Interim, NASA MERRA, NCEP CFSR, and JRA-25. J Clim 24:4888-4906

Hong C-C, Li Y-H, Li T, Lee M-Y (2011) Impacts of central Pacific and eastern Pacific El Niños on tropical cyclone tracks over the western North Pacific. Geophys Res Lett 38:L16712. https://doi. org/10.1029/2011GL048821

Hong C-C, Wu KY, Li T (2016) Influence of climate regime shift on the interdecadal change in tropical cyclone activity over the Pacific Basin during the middle to late 1990s. Clim Dyn 47:2587-2600

Hsu PC, Chu PS, Murakami H, Zhao X (2014) An abrupt decrease in the late-season typhoon activity over the western North Pacific. J Clim 27:4296-4313

Hu C, Yang S, Wu Q, Zhang T, Zhang C, Li Y, Deng K, Wang T, Chen J (2016) Reinspecting two types of El Niño: a new pair of Niño indices for improving real-time ENSO monitoring. Clim Dyn 47(12):4031-4049

Huang B, Banzon VF, Freeman E, Lawrimore J, Liu W, Peterson TC, Smith TM, Thorne PW, Woodruff SD, Zhang H-M (2015) Extended reconstructed sea surface temperature version 4 (ERSST. v4). Part I: upgrades and intercomparisons. J Clim 28:911-930

Huang B, Thorne P, Smith T, Liu W, Lawrimore J, Banzon V, Zhang $\mathrm{H}$, Peterson T, Menne M (2016) Further exploring and quantifying uncertainties for Extended Reconstructed Sea Surface Temperature (ERSST) Version 4 (v4). J Clim 29:3119-3142. https://doi. org/10.1175/JCLI-D-15-0430.1

Huangfu J, Huang R, Chen W, Feng T, Wu L (2017) Interdecadal variation of tropical cyclone genesis and its relationship to the monsoon trough over the western North Pacific. Int J Climatol 37:3587-3596. https://doi.org/10.1002/joc.4939

Kanamitsu M, Ebisuzaki W, Woolen J, Yang S-K, Hnilo JJ, Fiorino M, Potter GL (2002) NCEP-DOE AMIP-II reanalysis (R-2). Bull Am Meteorol Soc 83:1631-1643 
Kao H-Y, Yu J-Y (2009) Contrasting eastern-Pacific and central Pacific types of El Niño. J Clim 22:615-632. https://doi. org/10.1175/2008JCLI2309.1

Kendall MG (1975) Rank correlation methods. Charles Griffin, London, p. 202

Kim HM, Webster PJ, Curry JA (2009) Impact of shifting patterns of Pacific Ocean warming on north Atlantic tropical cyclones. Science 325:77-80

Kim HM, Webster PJ, Curry JA (2011) Modulation of North Pacific tropical cyclone activity by the three phases of ENSO. J Clim 24:1839-1849

Kosaka Y, Xie SP (2013) Recent global warming hiatus tied to equatorial Pacific surface cooling. Nature 501:403-407

Kug JS, Jin F-F, An SI (2009) Two types of El Niño events: cold tongue El Niño and warm pool El Niño. J Clim 22:1499-1515

Lander MA (1994) An exploratory analysis of the relationship between tropical storm formation in the western North Pacific and ENSO. Mon Weather Rev 122:636-651

Lee T, McPhaden MJ (2010) Increasing intensity of El Niño in the central-equatorial Pacific. Geophys Res Lett 37:L14603. https:// doi.org/10.1029/2010GL044007

Lin I-I, Chan JCL (2015) Recent decrease in typhoon destructive potential and global warming implications. Nat Commun 6:7182. https ://doi.org/10.1038/ncomms8182

Liu KS, Chan JCL (2013) Inactive period of western North Pacific tropical cyclone activity in 1998-2011. J Clim 26:2614-2630

Mann HB (1945) Non-parametric test against trend. Econometrica 13:245-259. https://doi.org/10.2307/1907187

Mann HB, Whitney DR (1947) On a test of whether one of two random variables is stochastically larger than the other. Ann Math Stat 18:50-60. https://doi.org/10.1214/aoms/1177730491

Maue RN (2011) Recent historically low global tropical cyclone activity. Geophys Res Lett 38:L14803. https://doi.org/10.1029/2011G L047711

Mendelsohn R, Emanuel K, Chonabayashi S, Bakkensen L (2012) The impact of climate change on global tropical cyclone damage. Nat Clim Change 2:205-209. https://doi.org/10.1038/nclimate1357

Peduzzi P, Chatenoux B, Dao H, De Bono A, Herold C, Kossin J, Mouton F, Nordbeck O (2012) Global trends in tropical cyclone risk. Nat Clim Chang 2:289-294. https://doi.org/10.1038/nclimate1410

Pielke R Jr, Gratz J, Landsea C, Collins D, Saunders M, Musulin R (2008) Normalized hurricane damage in the United States: 19002005. Nat Hazards Rev 9:29

Ren H-L, Jin F-F (2011) Niño indices for two types of ENSO. Geophys Res Lett 38:L04704. https://doi.org/10.1029/2010GL046031

Tu JY, Chou C, Chu PS (2009) The abrupt shift of typhoon activity in the vicinity of Taiwan and its association with western North Pacific-East Asian climate change. J Clim 22(13):3617-3628

Verdon DC, Franks SW (2006) Long-term behaviour of ENSO: Interactions with the PDO over the past 400 years inferred from paleoclimate records. Geophys Res Lett. https://doi.org/10.1029/2005G L025052

Vergados P, Mannucci AJ, Ao CO (2014) Assessing the performance of GPS radio occultation measurements in retrieving tropospheric humidity in cloudiness: A comparison study with radiosondes, ERA-Interim, and AIRS data sets. J Geophys Res- Atmos 119:7718-7731. https://doi.org/10.1002/2013JD021398

Wang B, Chan JCL (2002) How strong ENSO events affect tropical storm activity over the western North Pacific. J Clim 13:1517-1536

Wang X, Liu H (2015) PDO modulation of ENSO effect on tropical cyclone rapid intensification in the western North Pacific. Clim Dyn 46:15-28. https://doi.org/10.1007/s00382-01522563-8

Wang C, Wu L (2016) Interannual shift of the tropical upper-tropospheric trough and its influence on tropical cyclone formation over the western North Pacific. J Clim 29:4203-4211. https://doi. org/10.1175/JCLI-D-15-0653.1
Wang B, Yang Y, Ding Q, Murakami H, Huang F (2010) Climate control of the global tropical storm days (1965-2008). Geophys Res Lett 37:L07704. https://doi.org/10.1029/2010GL042487

Wang B, Liu J, Kim HJ, Webster PJ, Yim SY, Xiang B (2013a) Northern hemisphere summer monsoon intensified by Mega-El Niño/ Southern oscillation and Atlantic multidecadal oscillation. PNAS, https://doi.org/10.1073/pnas.1219405110

Wang B, Xiang B, Lee JY (2013b) Subtropical high predictability establishes a promising way for monsoon and tropical storm predictions. PNAS. https://doi.org/10.1073/pnas.1212646110

Wang C, Li C, Mu M, Duan W (2013c) Seasonal modulations of different impacts of two types of ENSO events on tropical cyclone activity in the western North Pacific. Clim Dyn 40(11-12):2887-2902

Wang XD, Wang C, Zhang L, Wang X (2015) Multidecadal variability of tropical cyclone rapid intensificatin in the western North Pacific. J Clim 28:3806-3820

Wang C, Deser C, Yu J-Y, DiNezio P, Clement A (2016) El Niño and Southern Oscillation (ENSO): a review. Coral reefs of the Eastern Tropical Pacific: persistence and loss in a dynamic. In: Environment PW, Glynn DP, Mazello, Enoch IC (eds) Coral reefs of the world, vol 8. Springer Netherlands, Dordrecht, pp 85-106

Wilcoxon $F$ (1945) Individual comparisons by ranking methods. Biom Bull 1:80-83. https://doi.org/10.2307/3001968

Wilks DS (2006) On "field significance" and the false discovery rate. J Appl Meteorol Climatol 45(9):1181-1189

Xiang B, Wang B, Li T (2013) A new paradigm for the predominance of standing Central Pacific warming after the late 1990s. Clim Dyn. https://doi.org/10.1007/s00382-012-1427-8

Yu J-Y, Kim ST (2010) Identification of Central-Pacific and EasternPacific types of ENSO in CMIP3 models. Geophys Res Lett 37:L15705. https://doi.org/10.1029/2010GL044082

Yu J-Y, Zou Y, Kim ST, Lee T (2012) The changing impact of El Niño on US winter temperatures. Geophys Res Lett 39:15702. https:// doi.org/10.1029/2012GL052483

Zhan R, Wang Y, Lei X (2011) Contributions of ENSO and east Indian Ocean SSTA to the interannual variability of Northwest Pacific tropical cyclone frequency. J Clim 24:509-521

Zhang Q, Liu Q, Wu L (2009) Tropical cyclone damages in China 1983-2006. Bull Am Meteorol Soc 90:489-495

Zhang J, Wu L, Ren F, Cui X (2013) Changes in Tropical Cyclone Rainfall in China. J Meteorol Soc Jpn 91:585-595

Zhao H (2016) A downscaling technique to simulate changes in western North Pacific tropical cyclone activity between two types of El Niño events. Theor Appl Climatol 123:487-501. https://doi. org/10.1007/s00704-015-1374-5

Zhao H, Wang C (2016) Interdecadal Modulation on the Relationship between ENSO and Typhoon Activity during the Late Season in the Western North Pacific. Clim Dyn 47(1):315-328. https://doi. org/10.1007/s00382-015-2837-1

Zhao H, Wu L, Zhou W (2010) Assessing the influence of the ENSO on tropical cyclone prevailing tracks in the western North Pacific. Adv Atmos Sci 27(6):1361-1371

Zhao H, Wu L, Zhou W (2011) Interannual changes of tropical cyclone intensity in the western north Pacific. J Meteorol Soc Jpn 89(3):243-253. https://doi.org/10.2151/jmsj.2011-305

Zhao J, Zhan R, Wang Y, Tao L (2016) Intensified interannual relationship between tropical cyclone genesis frequency over the Northwest Pacific and the SST gradient between the Southwest Pacific and the Western Pacific Warm Pool since mid-1970s. J Clim 29:3811-3830. https://doi.org/10.1175/JCLI-D-15-0729.1

Zhou BT, Cui X (2014) Interdecadal change of the linkage between the North Atlantic Oscillation and the tropical cyclone frequency over the western North Pacific. Sci China Earth Sci 57:2148-2155 